\title{
Commentary Coming soon to an ICU near you: severe pandemic influenza in ICU patients in Spain Steven M Opal
}

Warren Alpert Medical School of Brown University, Infectious Disease Division, Memorial Hospital of Rhode Island, 111 Brewster Street, Pawtucket, RI 02860, USA

Corresponding author: Steven M Opal, steven_opal@brown.edu

Published: 21 October 2009

Critical Care 2009, 13:196 (doi:10.1186/cc8112)

This article is online at http://ccforum.com/content/13/5/196

(c) 2009 BioMed Central Ltd

See related research by Rello et al., http://ccforum.com/content/13/5/R148

\begin{abstract}
A novel strain of swine influenza $\mathrm{A} \mathrm{H} 1 \mathrm{~N} 1$ has already disseminated worldwide and has become a major clinical problem for intensive care units in selected areas. Many regions in the southern hemisphere are currently struggling to keep up with the influx of severely affected patients with acute respiratory failure from primary influenza pneumonia. The northern hemisphere is bracing for a similar surge of patients over this winter's influenza season. This initial report of ventilatory needs for patients with severe influenza pneumonia in Spanish intensive care units provides a useful guide of what to expect and how to respond to the challenge of pandemic influenza.
\end{abstract}

In the current issue of Critical Care, Rello and colleagues [1] describe their initial experience with severe swine influenza pneumonia in Spanish intensive care units (ICUs). The experience in Spain is similar to that reported from Mexico City [2] and the US [3], emphasizing an abrupt onset and severe hypoxemic illness, with acute respiratory failure developing often in young, previously healthy individuals (the median age in this study was 36 years). The World Health Organization declared swine flu a level 6 public health emergency soon after the emergence and worldwide spread of the influenza A/Mexico City/2009 (H1N1) virus [4]. This novel swine influenza strain is highly transmissible person-to-person, although severe human disease occurs at low frequency. The currently estimated population mortality rate is $0.1 \%$, but in the ICU patients reported in the study of Rello and colleagues [1], it is $18.8 \%$. Although this virus lacks many of the features of the highly pathogenic influenza A H1N1 1918 strain [5-7] or the avian $\mathrm{H} 5 \mathrm{~N} 1$ strain $[8,9]$, it could cause hundreds of thousands of deaths worldwide if an anticipated population attack rate of $10 \%$ to $50 \%$ is confirmed over the next year.

The influenza virus deploys a frontal attack strategy by rapidly invading the respiratory epithelium of susceptible individuals, where it induces diffuse necrosis, marked inflammatory changes, intra-alveolar hemorrhage, and a highly productive cough. The virus replicates exponentially in human cells and then is transmitted via respiratory aerosol to other susceptible human hosts. This process repeats itself throughout the human populations until such time as sufficient antibodies and perhaps other innate and acquired immune responses curtail further spread of the virus. The pathogenicity of this virus depends on rapid cleavage and activation of its primary attachment protein hemagglutinin (HA) and efficient release from cells by its neuraminidase enzyme [5]. Other virulence factors, seen most prominently in the 1918 and avian H5N1 viruses, include polymerase basic-1 (PB1), PB2, and nonstructural 1 (NS1) proteins. The PB1-F2 protein primarily traffics influenza virus to the outer membrane of mitochondria, inducing cellular energy loss and eventual cell death $[10,11]$. The NS1 also promotes apoptosis and rapid loss of cell viability. Fortunately, the current swine flu pandemic strain lacks a number of these important virulence determinants [12]. The virus is intrinsically resistant to amantadine and similar drugs but retains its susceptibility, for the most part, to the neuraminidase inhibitors oseltamivir and zanamivir. However, the risk of its developing oseltamivir resistance is real [13], and this demands caution against the profligate use of these anti-viral agents.

The current pandemic strain is a quadruple re-assortant virus with segments of its genome derived from Eurasian swine, North American swine, avian species, and human influenza virus strains. The HA from human-adapted strains binds primarily to sialic acids bound by alpha 2-6 linkages to galactose found on surface glycoproteins along the respiratory epithelium. Avian strains prefer alpha 2-3 binding sites, whereas swine influenza viruses usually bind to either alpha 2-3 or alpha 2-6 sialic acid-galactose linkages. This

$\mathrm{HA}=$ hemagglutinin; $\mathrm{ICU}=$ intensive care unit; $\mathrm{NS} 1=$ nonstructural $1 ; \mathrm{PB}=$ polymerase basic. 
probably explains why swine are important as intermediate hosts for novel pandemic flu strains that periodically affect human populations [5].

In their report, Rello and colleagues [1] point out a disproportionately high frequency of severe pneumonia in pregnant women and obese patients. The risk of severe influenza in pregnant women during pandemics has been well known for decades [14]. Less well characterized is the increased risk of severe influenza pneumonia in obese patients. This observation might not be mere coincidence; obese patients are more difficult to ventilate due to chest wall restriction, and adipocytes are immunologically active cells with fat tissue replete with macrophages [15]. Adipose tissue generates proinflammatory cytokines and this may conspire with a systemic inflammatory response from influenza pneumonia to increase severity and mortality rates in obese patients. The events that have taken place in Spanish ICUs are likely to be repeated many times over in ICUs throughout the world.

Pandemic influenza generally occurs only once or twice during a professional career. How well, or how poorly, we respond as a global community will be judged for decades to come. How well prepared are we? Will the new $\mathrm{H} 1 \mathrm{~N} 1$ vaccines become available in time to protect susceptible human populations? Will supplies of anti-viral agents be sufficient and be equitably distributed throughout the world? The evidence so far suggests that there will be substantial shortfalls in supplies of both $[10,11,16]$, and these shortfalls will likely cause severe difficulties in developing countries [17].

Could we use our current knowledge of the immunology and host response to influenza to devise an effective approach to help patients with severe pneumonia? The pathologic series of events leading to death from influenza likely has hereditary [18], environmental [19], and inflammatory [7,9] components. Is there too much inflammation in primary influenza pneumonia, or is there insufficient inflammation resulting in poor viral clearance? How many of the fatalities from influenza pneumonia are attributable to secondary bacterial pneumonia? Individual variation in the host response to influenza virus infection is probably an important determinant of ultimate outcome. Could we intelligently determine specific patient needs and intervene appropriately in severely afflicted patients?

A number of currently available agents on the market might provide some benefit in managing severe, primary, influenza pneumonia $[10,11,20]$. Would corticosteroid administration benefit selected patients or worsen viral shedding and mortality in severe influenza? Should we give immunoadjuvants or immune suppressive agents in combination with anti-viral agents? These clinical questions need to be studied expeditiously and conclusively answered. Will we move forward together with a rapidly expanding, evidence-based approach to understanding influenza and its optimal manage- ment and be willing to share our knowledge and financial assets equitably between richer and poorer nations? As this pandemic evolves, the answers to these and other questions will become starkly evident within the next 12 months.

\section{Competing interests}

The author declares that they have no competing interests.

\section{References}

1. Rello J, Rodríguez A, Ibañez P, Socias L, Cebrian J, Marques A, Guerrero J, Ruiz-Santana S, Marquez E, Del Nogal-Saez F, Alvarez-Lerma F, Martínez S, Ferrer M, Avellanas M, Granada R, Maraví-Poma E, Albert P, Sierra R, Vidaur L, Ortiz P, Prieto del Portillo I, Galván B, León-Gil C, the H1N1 SEMICYUC working group: Intensive care patients with severe novel H1N1 influenza viral pneumonia in Spain. Crit Care 2009, 13:R148.

2. Chowell G, Bertozzi SM, Colchero MA, Lopez-Gatell H, AlpucheAranda C, Hernandez M, Miller MA: Severe respiratory disease concurrent with the circulation of $\mathrm{H} 1 \mathrm{~N} 1$ influenza. $\mathrm{N}$ Engl J Med 2009, 361:674-679.

3. Shinde V, Bridges CB, Uyeki TM, Shu B, Balish A, Xu X, Lindstrom S, Gubareva LV, Deyde V, Garten RJ, Harris M, Gerber S, Vagasky S, Smith F, Pascoe N, Martin K, Dufficy D, Ritger K, Conover C, Quinlisk P, Klimov A, Bresee J, Finelli L: Triple-reassortant swine influenza $A(\mathrm{H} 1)$ in humans in the United States, 2005-2009. N Engl J Med 2009, 360:2616-2625.

4. Khan K, Arino J, Hu W, Raposo P, Sears J, Calderon F, Heidebrecht C, Macdonald M, Liauw J, Chan A, Gardam M: Spread of a novel influenza $A(\mathrm{H} 1 \mathrm{~N} 1)$ virus via global airline transportation. N Engl J Med 2009, 361:212-214.

5. Kobasa D, Takada A, Shjinya K, Hatta M, Halfmann P, Therlault S, Suzuki H, Nishimura H, Mltamura K, Sugaya, N, Usul T, Murata T, Maeda Y, Watanabe S, Suresh M, Suzuki T, Suzuki Y, Feldmann $\mathrm{H}$ : Enhanced virulence of influenza $A$ viruses with the haemagglutinin of the 1918 pandemic virus. Nature 2004, 431: 703-707.

6. Tumpey TM, Garcia-Sastre A, Mikulasova A, Taubenberger JK, Swayne DE, Palese P, Basler CF: Existing antivirals are effective against influenza viruses with genes from the 1918 pandemic virus. Proc Natl Acad Sci U S A 2002, 99:13849-13854.

7. Gamblin SJ, Haire LF, Russell RJ, Stevens DJ, Xiao B, Ha Y, Vasisht N, Steinhauer DA, Daniels RS, Elliott A, Wiley DC, Skehel $\mathrm{JJ}$ : The structure and receptor binding properties of the 1918 influenza hemagglutinin. Science 2004, 303:1838-1842.

8. Guan Y, Poon LLM, Ellis TM, Lim W, Lipatov AS, Chan KH, SturmRamirez KM, Cheung CL, Leung YHC, Yuen KY, Webster RG, Peiris JSM: H5N1 influenza: a protean pandemic threat. Proc Natl Acad Sci U S A 2004, 101:8156-8161.

9. Cheung CY, Poon LLM, Lau AS, Luk W, Lau YL, Shortridge KF, Gordon S, Guan Y, Peiris JSM: Induction of proinflammatory cytokines in human macrophages by influenza A (H5N1) viruses: a mechanism for the unusual severity of human disease. Lancet 2002, 360:1831-1837.

10. Fedson DS: Confronting the next influenza pandemic with anti-inflammatory and immunomodulatory agents: why they are needed and how they might work. Influenza Other Respi Viruses 2009, 3:129-142.

11. Fedson D: Meeting the challenge of influenza pandemic preparedness in developing countries. Emerg Infect Dis 2009, 15: 365-371.

12. Garten RJ, Davis CT, Russell CA, Shu B, Lindstrom S, Balish A, Sessions WM, Xu, X, Skepner E, Deyde V, Okomo-Adhiambo M, Gubareva L, Barnes J, Smith CB, Emery SL, Hillman MJ, Rivailler P, Smagala J, de Graaf M, Burke DF, Fouchier RAM, Pappas C, Alpuche-Aranda CM, López-Gatell H, Olivera H, López I, Myers CA, Faix D, Blair PJ, Yu C, et al.: Antigenic and genetic characteristics of swine-origin 2009 A (H1N1) influenza viruses circulating in humans. Science 2009, 325:197-201.

13. Poland GA, Jacobson RM, Ovsyannikova IG: Influenza virus resistance to antiviral agents: a plea for rational use. Clin Infect Dis 2009, 48:1254-1256.

14. Jamieson DJ, Honein MA, Rasmussen SA, Williams JL, Swerdlow DL, Biggerstaff MS, Lindstrom S, Louie JK, Christ CM, Bohm SR, Fonseca VP, Ritger KA, Kuhles DJ, Eggers P, Bruce H, Davidson 
HA, Lutterloh E, Harris ML, Burke C, Cocoros N, Finelli L, MacFarlane KF, Shu B, Olsen SJ, and the Novel Influenza A (H1N1) Pregnancy Working Group: H1N1 2009 influenza virus infection during pregnancy in the USA. Lancet 2009, 374:451-458.

15. Bastard JP, Maachi M, Laqathu C, Kim MJ, Caron M, Vidal H, Capeau J, Feve B: Recent advances in the relationship between obesity, inflammation and insulin resistance. Eur Cytokine Netw 2006, 17:4-12.

16. Fedson D, Dunnill P: From scarcity to abundance: pandemic vaccines and other agents for "Have Not" countries. J Public Health Policy 2007, 28:322-340.

17. Murray CJL, Lopez AD, Chin B, Feehan D, Hill KH: Estimation of potential global pandemic influenza mortality on the basis of vital registry data from the $1918-20$ pandemic: a quantitative analysis. Lancet 2006, 368:2211-2218.

18. Albright FS, Orlando P, Pavia AT, Jackson GG, Cannon Albright LA: Evidence for a heritable predisposition to death due to influenza. J Infect Dis 2008, 197:18-24.

19. Morens DM, Taubenberger JF, Fauci AS: Predominant role of bacterial pneumonia as a cause of death in pandemic influenza: implications for pandemic influenza preparedness. $J$ Infect Dis 2008, 198:962-970.

20. Palamara AT, Nencioni L, Aquilano K, De Chiara G, Hernandez L, Cozzolino F, Ciriolo MR, Caraci E: Inhibition of influenza A virus replication by resveratrol. J Infect Dis 2005, 191:1719-1729. 